\title{
Great Britain, Blockades, and Neutral Rights: Royal Navy Operations during the Mexican- American War, 1846-1848
}

\section{Stanley Adamiak}

Although neutral during the Mexican American War (18468), Great Britain's Royal Navy had to navigate the war's naval component, particularly commerce raiding and blockades, as it sought to protect and promote trade and neutral rights. While able to use international pressure to limit privateering, handling the blockade proved more problematic. Although US policies largely mirrored British expectations in the Gulf of Mexico, along Mexico's Pacific coast, inconsistent US Navy actions created tension. The professionalism of both American and British naval officers and a willingness of both governments to compromise effectively diffused any potential crises.

Bien qu'elle soit restée neutre pendant la guerre américanomexicaine (1846-1848), la Marine royale de la Grande-Bretagne a dû s'occuper de l'aspect naval de la guerre, en particulier les corsaires marchands et les blocus commerciaux, alors qu'elle cherchait à protéger et à promouvoir le commerce et la neutralité des droits. Pour limiter la course, la Marine pouvait recourir à des pressions exercées au niveau international, mais la gestion des blocus s'est révélée plus difficile. Bien que les politiques américaines aient reflété en grande partie les attentes britanniques dans le golfe du Mexique, les mesures incohérentes prises par la Marine américaine ont créé des tensions le long de la côte pacifique du Mexique. Le professionnalisme des officiers de marine américains et britanniques et la volonté des deux gouvernements de faire des compromis ont efficacement dissipé toute crise potentielle.

The Northern Mariner / Le marin du nord 31, no. 2 (Summer 2021), 173-188 


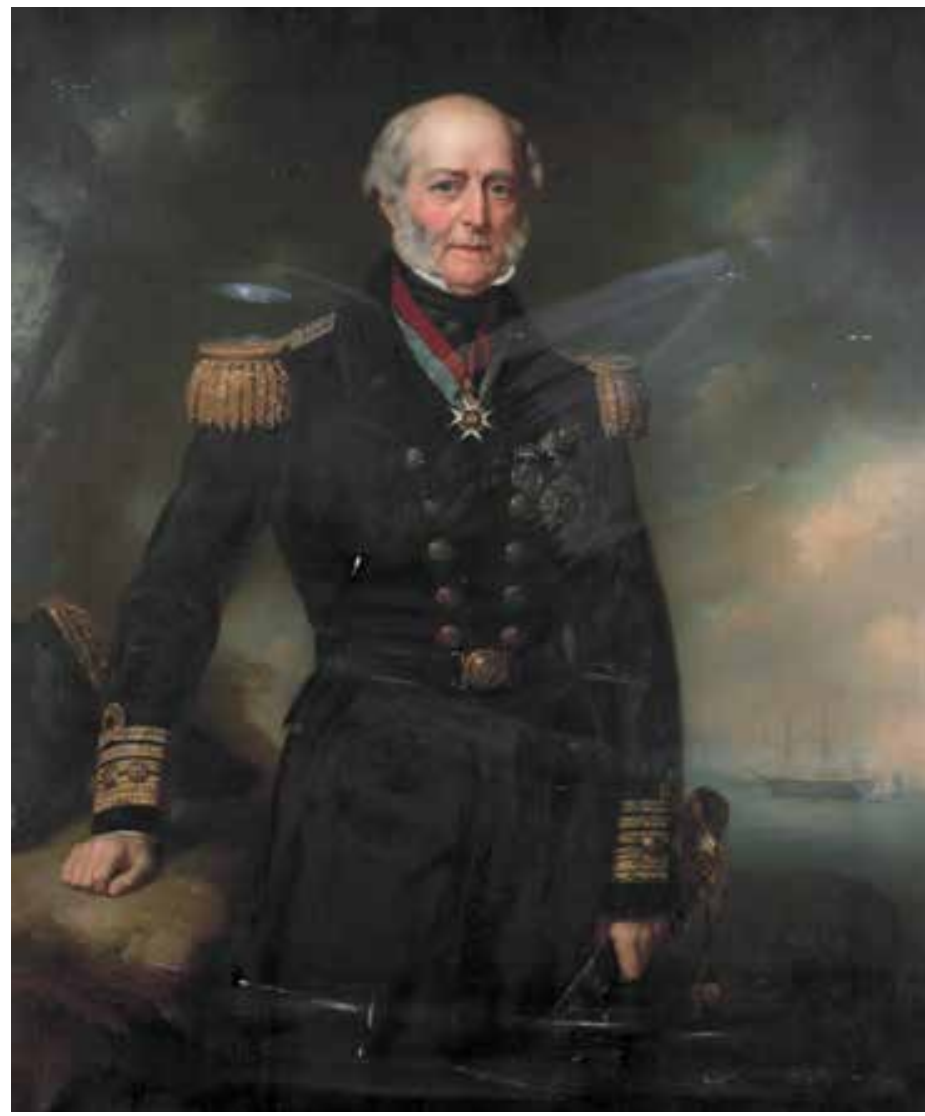

Sir George Francis Seymour, c. 1863. Painting by John Lucas. (Wikimedia Commons)

When Mexico and the United States went to war in May 1846, Great Britain found itself a protector of neutral rights in the region. As war loomed, Britain feared the United States Navy would impose a blockade on Mexican ports, including not only Tampico and Vera Cruz on the Gulf of Mexico, but Pacific ports such as Guaymas and Mazatlán, and Monterey and San Francisco further north on the California coast. During the Napoleonic Wars, Britain blockaded all of the French Empire and tightly regulated neutral trade. The US argued a blockade needed to be localized and enforceable with liberal provisions for neutrals, a stand that contributed to war in 1812. Now the roles were reversed, with the US seeking to use its naval power and Britain wanting to moderate its impact. To offset American naval superiority, Mexico threatened to unleash privateers, but privateers in Latin American revolutions proved to be more pirate than patriot. Throughout the conflict, the US and Great Britain largely agreed on the rules of blockade. In the Gulf of Mexico, there was little conflict. Along Mexico's extensive Pacific shores, however, overly optimistic US commanders created controversy by proclaiming an unenforceable blockade of the entire coast. Throughout the conflict, Royal 


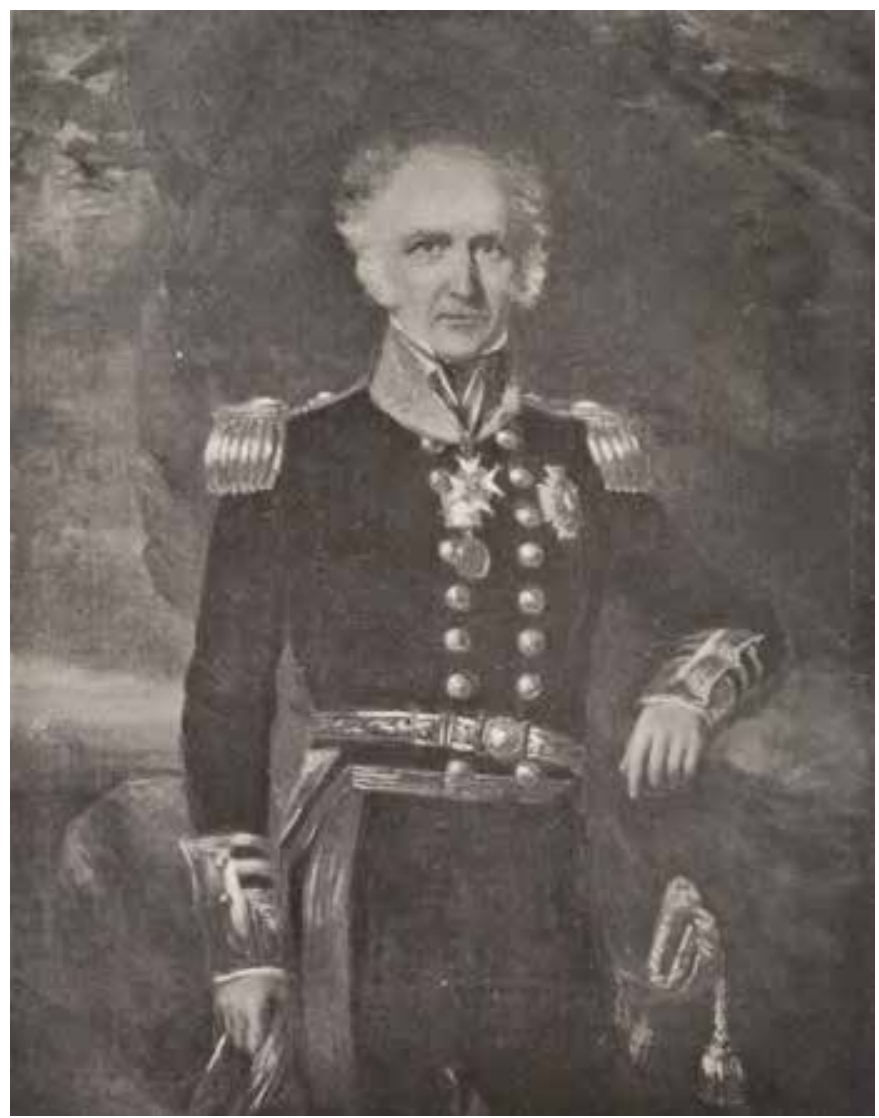

Vice Admiral Sir Francis Austen. Austen was an elder brother of the novelist Jane Austen. (J.H. Hubback and E.C. Hubback, Jane Austen's Sailor Brothers)

Navy officers, determined to maintain strict neutrality, exhibited a professionalism towards their American counterparts and diffused potential crises through careful diplomacy.

Preserving British neutrality and trade largely fell to two Royal Navy squadrons. Vice Admiral Sir Francis Austen commanded the North America and West Indies Station. A competent officer with decades of service, his squadron's ten vessels were spread thinly, from policing the waters of the Canadian fisheries, to conducting anti-piracy and slave patrols off South America, with bases in Halifax, Jamaica, and a depot in Bermuda. Austen never visited the Mexican theater, instead relying upon his officers on station. With monthly Royal Mail steamers running between the gulf and England, his officers often reported to both him and the Admiralty at the same time. ${ }^{1}$ His counterpart in the Pacific, Rear Admiral Sir George Seymour was not so fortunate. With cruising grounds that included the eastern Pacific from the Bering Straits to Antarctica, his support depended upon

1 Francis Austen Papers, 27 May 1846, 17 May 1848, AUS 12, National Maritime Museum (NMM), Greenwich, UK. 


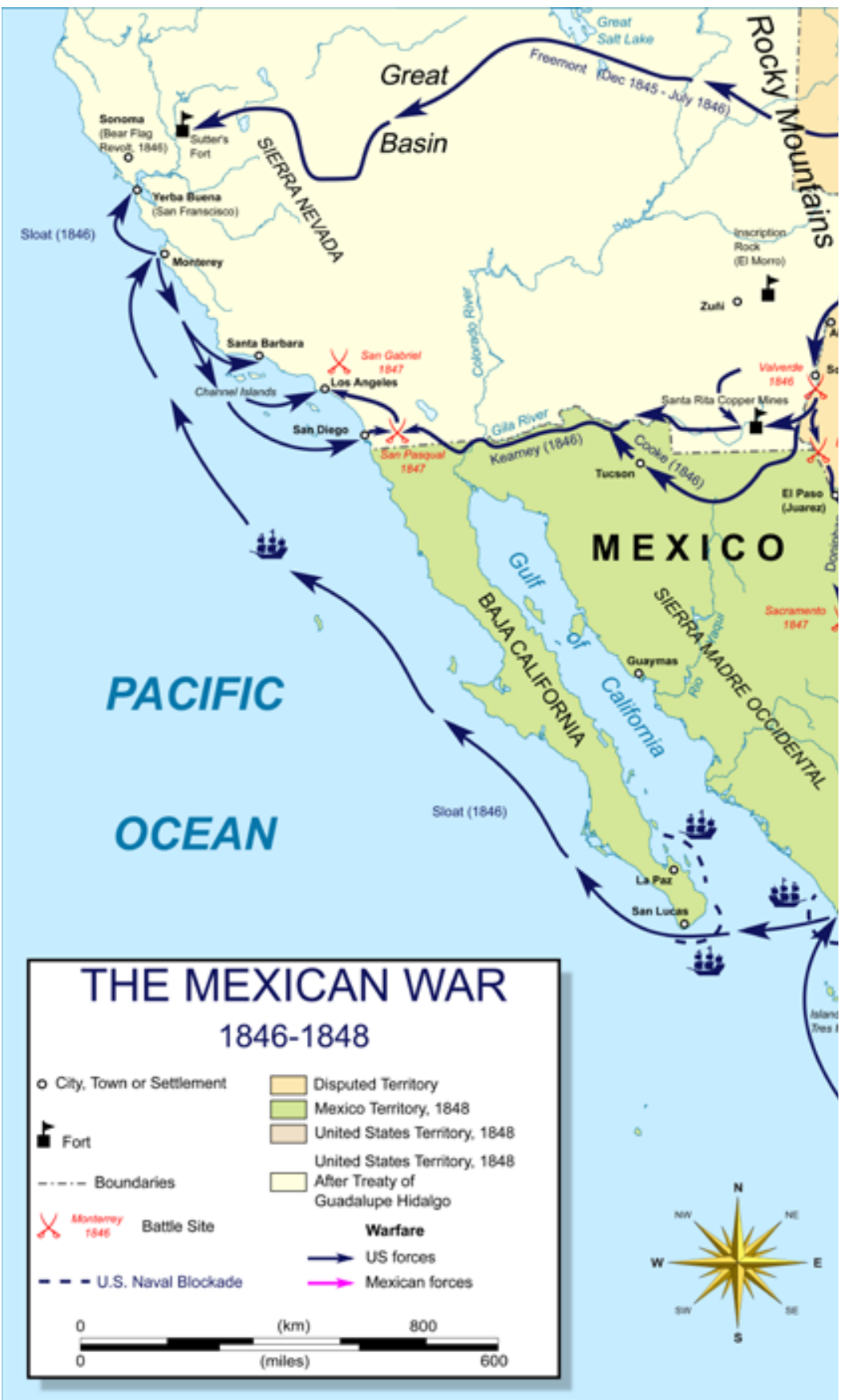




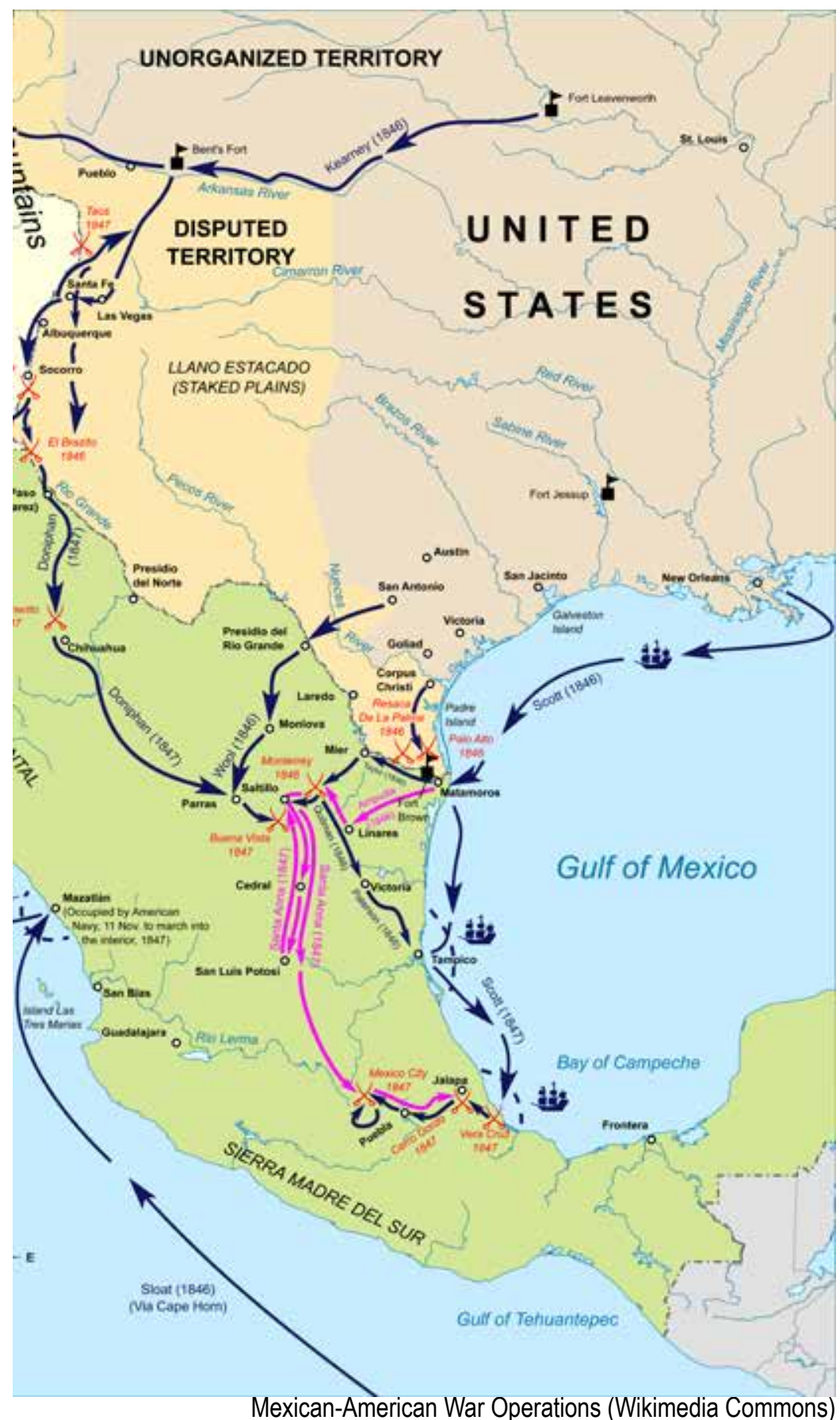


depots in Valparaiso (Chile), Callao (Peru), and Hawaii. ${ }^{2}$ Seymour's tenuous line of communications involved either delivery overland via Mexican mail or across the Panamanian isthmus. Since he constantly moved, he was desperate for information from dispatches, diplomats, or newspapers. ${ }^{3}$ Assisting these two officers were several diplomats in Mexico, from consuls in ports to Minister Plenipotentiary Charles Bankhead in Mexico City, and minister to the US, Richard Pakenham. The Foreign Office made clear the consuls would defer to naval officers on wartime maritime issues. ${ }^{4}$ Together, these diplomatic and naval officers achieved Britain's desire to maintain its neutrality while

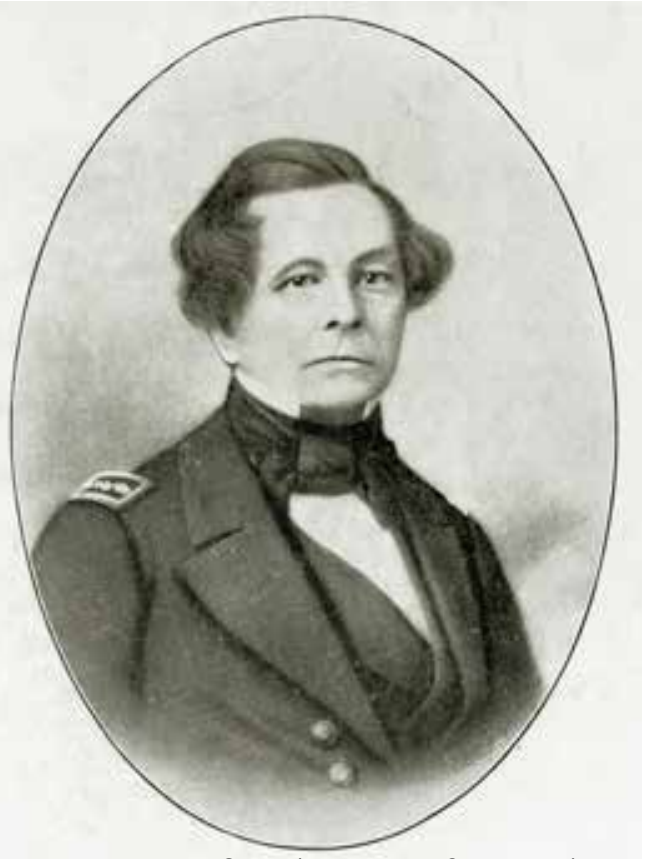

Commodore John Sloat (Wikimedia Commons) minimizing threats to its economic interests.

When the US annexed Texas in spring 1845, British officials braced for war. Both squadron commanders complained their forces were stretched too thin and requested reinforcements. ${ }^{5}$ Unfortunately, the Admiralty found its global commitments and fear of war with France made reinforcements impossible. ${ }^{6}$ Both Bankhead and Austen feared war would mean an American blockade and Mexico would undoubtedly turn to privateers. Bankhead warned the Mexicans against unregulated privateering, while Austen feared "numerous mercenary Privateers mistaking our Vessels for Americans."” Bankhead blamed conflict on an aggressive

2 Barry M. Gough, "The Records of the Royal Navy's Pacific Station," Journal of Pacific History 4 (1969): 147.

3 Seymour to Admiralty, 12 June 1846, Official Letterbook, Papers of Admiral George Seymour, digital scan of microfilm, National Library of Australia (NLA), https://nla.gov.au/nla.obj1127160519/findingaid. See also Barry M. Gough, "The Royal Navy and the Oregon Crisis, 18441846," British Columbia Studies 9 (Spring 1971): 24, https://ojs.library.ubc.ca/index.php/bcstudies/ article/view/689/735.

4 "List of all the Consuls-General, Consuls, Vice-Consuls, and Consular Agents," 23 July 1846, House of Commons, Command Papers, Parliamentary Papers, 8. Britain maintained consulates in Mexico City, Tampico, Matamoros, Vera Cruz, San Blas, and California.

5 Austen to Admiralty, 29 April 1845, 13 September 1845, ADM 1/5542, The National Archives (TNA), Kew, UK.

6 Austen to Lambert, 27 May 1846, ADM 1/5560, TNA; Admiralty to Foreign Office, 9 June 1846, ADM $1 / 5568$, TNA.

7 Bankhead to Austen, 26 July 1845, enclosed in Admiralty to Austen, 10 September 1845, ADM 
Mexican policy and the "readiness of the Americans to avail themselves" of any "overt act," a view shared by both Austen and Seymour. ${ }^{8}$

Seymour feared a wider conflict. His command faced several crises: the French in Tahiti, the Americans in Oregon, and a potential Mexican American War. The latter two were interrelated because he anticipated the first step in an Anglo-American conflict would be the US seizure of San Francisco in Mexican California. ${ }^{9}$ With the increasingly belligerent tone from US President James K. Polk over Oregon, and American machinations in northern California, Seymour developed contingency plans. ${ }^{10}$ Royal Navy vessels visited the California and Oregon coasts. He was sympathetic to a British consul's effort to foment an independence movement that would declare California a British protectorate, but following orders from the Foreign Office, instructed his officers not to intervene. If there was an American coup, or seizure without a state of war, they were to make clear British opposition to a "foreign power" gaining exclusive control, unless a result of actual and declared hostilities. ${ }^{11}$ Seymour occasionally met with his American counterpart, Commodore John Sloat. In July 1845, Seymour remained diplomatic, but left Sloat with the impression that he would act decisively in an Anglo-American war. The admiral could not ignore a growing American naval presence off Mexico's west coast. ${ }^{12}$ In hindsight, Seymour need not have worried about Oregon. Sloat's confidential orders were clear - his squadron was to concentrate on the Mexican coast and move on Upper California upon word

128/2, TNA; Austen to Admiralty, 15 September 1845, ADM 1/5549, TNA.

8 Bankhead to Aberdeen, 30 July 1845, enclosure in Admiralty to Austen, 10 September 1845, ADM 128/2, TNA.

9 For Seymour's attitude on Oregon and California see Gough, "Royal Navy and the Oregon Crisis,"15-37.

10 Seymour to John Duarte, 15 July 1845, Special Order Book, Papers of Admiral George Seymour, NLA. See also Seymour to John Duarte, 14 January 1846, to Captain of commanding at Valparaiso, 14 February 1846 and 6 March 1846; and to John Gordon, 6 March 1846. The news that President Polk had rescinded the joint occupation of Oregon prompted Seymour to believe war with America over Oregon was likely. Contingency plans for concentrating RN forces off Oregon were in motion in March 1846, with orders to raid US commerce, destroying it rather than capturing it. The lack of friendly ports and shortages of prize crews influenced this decision. Seymour was "most desirous" of peace.

11 Seymour to John Gordon, 12 August 1845, "Special Letterbook," Papers of Admiral George Seymour, NLA. British efforts in California are well documented, aside from Gough, "Royal Navy and Oregon Crisis," see AP Nassir, "International Rivalry and the Establishment of the British Consulate," California Historical Society Quarterly 46, no. 1 (March 1967): 53-70, http:// doi.org/10.2307/25154185; Ernest A. Wiltsee, "The British Vice Consul in California and the Events of 1846," California Historical Society Quarterly 10, no. 2 (June 1931): 118-119, http:// doi.org/10.2307/25160459; Sheldon G. Jackson, "Two British Plots in Alta California," Southern California Quarterly 55, no. 2 (Summer 1973): 105-140, http://doi.org/10.2307/41170473.

12 Sloat to Bancroft, 29 July 1845, "Letters Received by the Secretary of the Navy from Commanding Officers of Squadrons," Pacific Squadron Letters, RG 45, Naval Records Collection of the Office of Naval Records and Library, microfilm copy, M89, National Archives and Records Administration (NARA), Washington, DC (at least part is now available on FOLD 3 database). 


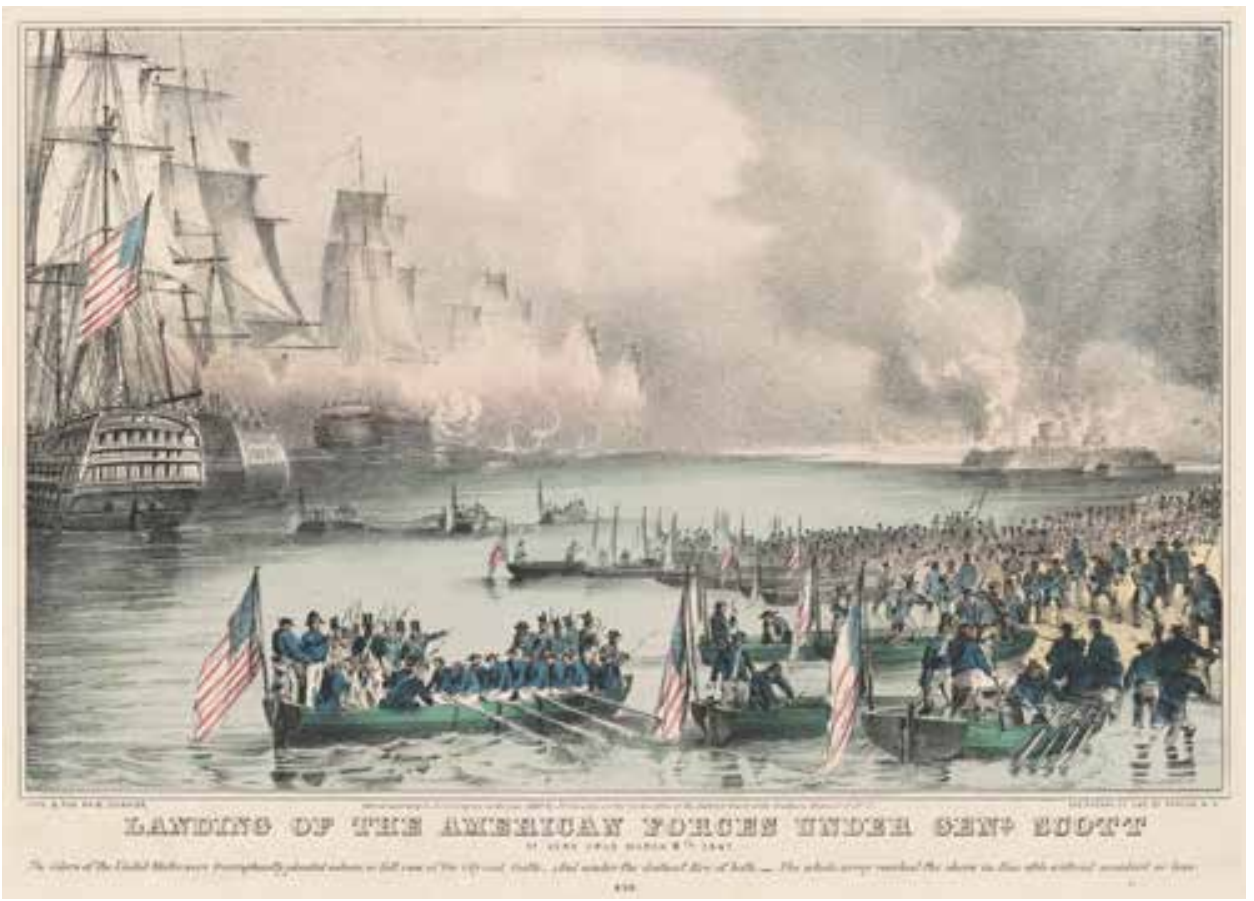

Landing of the American Force Under General Scott at Vera Cruz, 9 March 1847. Lithograph by N. Currier. (National Gallery of Art, Washington, DC)

of war with Mexico. ${ }^{13}$ Seymour anticipated the US would seize California and impose a "vigorous" blockade of the west coast. ${ }^{14}$ Ironically, the contingencies he cited never mentioned privateers. Perhaps, since only four British vessels visited Mexico's west coast in 1845 , it did not seem much of a concern. ${ }^{15}$

On 13 May 1846 Pakenham wrote to Austen, notifying him of the US declaration of war. ${ }^{16}$ On 27 May, Austen drafted orders dispatching three additional ships to the gulf. His officers would maintain the "strictest neutrality" which would require "particular delicacy" and "to avoid any misjudgment with the United States" while maintaining a "good feeling with both Powers." Any blockade needed to be "properly constituted" with adequate notice. The blockade must have sufficient force to be valid and if even temporarily raised must be legally "reconstituted." Neutrals should be allowed to trade all items except "arms, ammunition, timber for shipbuilding, naval stores, and provisions, in some cases." A priority would be to allow the monthly Royal Mail Service steamers to access Vera Cruz and Tampico. ${ }^{17}$

13 Bancroft to Sloat, (secret and confidential) 24 June 1845, "Mexican War Correspondence," House Executive Document 60, 30th Congress, 1st Session, 231.

14 Seymour to Admiralty, 7 March 1845 and 7 April 1846, Official Letterbook, Papers of Admiral George Seymour, NLA.

15 "Commercial Tariffs and Regulations, Resources, and Trade ... Part the $16^{\text {th }}$, State of Mexico," Command Papers, House of Commons, 1846, 272-6. Courtesy of ProQuest.

16 Packenham to Austen, 13 May 1846, ADM 1/5560, TNA.

17 Austen to Lambert, 27 May 1846, ADM 1/5560, TNA. These conditions paralleled Conner's 
Even as Austen drafted these orders, Captain Richard Pelly on HMS Rose had already carried out most of these measures off Vera Cruz. The Americans provided Pelly with a formal declaration of blockade. Although the US squadron commander, Commodore David Conner, was not present, his subordinates addressed Pelly's concerns. Mail packets would continue to Vera Cruz and Tampico provided they only carried mail, neutral passengers, and their baggage. They would not transport any "merchandize" either in or out of the blockaded ports. British merchants would be allowed to import quicksilver and export silver specie temporarily, pending Conner's return. ${ }^{18}$

While the situation in Vera Cruz proceeded relatively amicably, the situation in Tampico was very confused. Arriving in early July, Captain George Lambert of HMS Edmyion assumed control of British forces off Mexico. In Tampico, a dispute arose between British merchants, the consul, and the American blockaders. Merchants wanted special exceptions for quicksilver, vanilla, and cochineal dye, which the French had allowed during their 1838 blockade. Merchants also wanted to export merchandise on mail steamers and to allow ships ignorant of the war to be allowed entry. What transpired was a series of negotiations between Lambert and Conner regarding the differences between Tampico and Vera Cruz. ${ }^{19}$ Austen accurately summed up the situation, noting that, "There appears to have been some difficulty at first, which was removed by Commodore [Conner], who appeared guided by the most liberal measures towards British Subjects." ${ }^{20}$ Merchants could continue to import quicksilver and export specie.

Learning of the war through Mexican newspapers in June 1846, Sloat sailed to Monterey. Seymour, acting upon the same news, followed a few days later. ${ }^{21}$ He had already sent HMS Juno to San Francisco Bay to gather intelligence. ${ }^{22}$ Seymour arrived in Monterey in early July to find that city and San Francisco in US possession. The presence of the 80-gun flagship HMS Collingwood created a stir, but Sloat and Seymour met over the course of a week and discussed the issues, with the American providing spars and other stores for Seymour's ship. ${ }^{23}$ Upon leaving, Seymour reminded the British consul who had backed a separatist

orders, Bancroft to Conner, 13 May 1846, "Mexican War Correspondence," House Executive Document 60, 30th Cong., 1st Sess., 231.

18 Austen to Admiralty, 20 June 1846, ADM 1/5560, TNA; Enclosures: Pelly to Austen, 1 June 1846; Fitzhugh to Pelly, 20 May 1846, ADM 1/5560, TNA.

19 Austen to Admiralty, 15 August 1846, ADM 1/5560, TNA. Enclosures: Lambert to Conner, 6 July 1846; Conner to Lambert 6 July 1846; Lambert to Conner, 25 July 1846, ADM 1/5560, TNA.

20 Austen to Admiralty, 7 August 1847, ADM 1/5560, TNA.

${ }_{21}$ Seymour to Admiralty, 12 June 1846, 13 June 1846, Official Letterbook, Papers of Admiral George Seymour, NLA.

22 Seymour to George Blake, 10 May 1846 and Memo, 11 May 1846, Special Order Book, Papers of Admiral George Seymour, NLA.

23 Seymour to Admiralty, 22 July 1846, Official Letterbook, Papers of Admiral George Seymour, NLA. He was disappointed that the harbor at San Francisco and its tremendous potential had been gained by the Americans. Sloat to George Bancroft, 31 July 1846, Pacific Squadron Letters, RG 45, M89, NARA. 


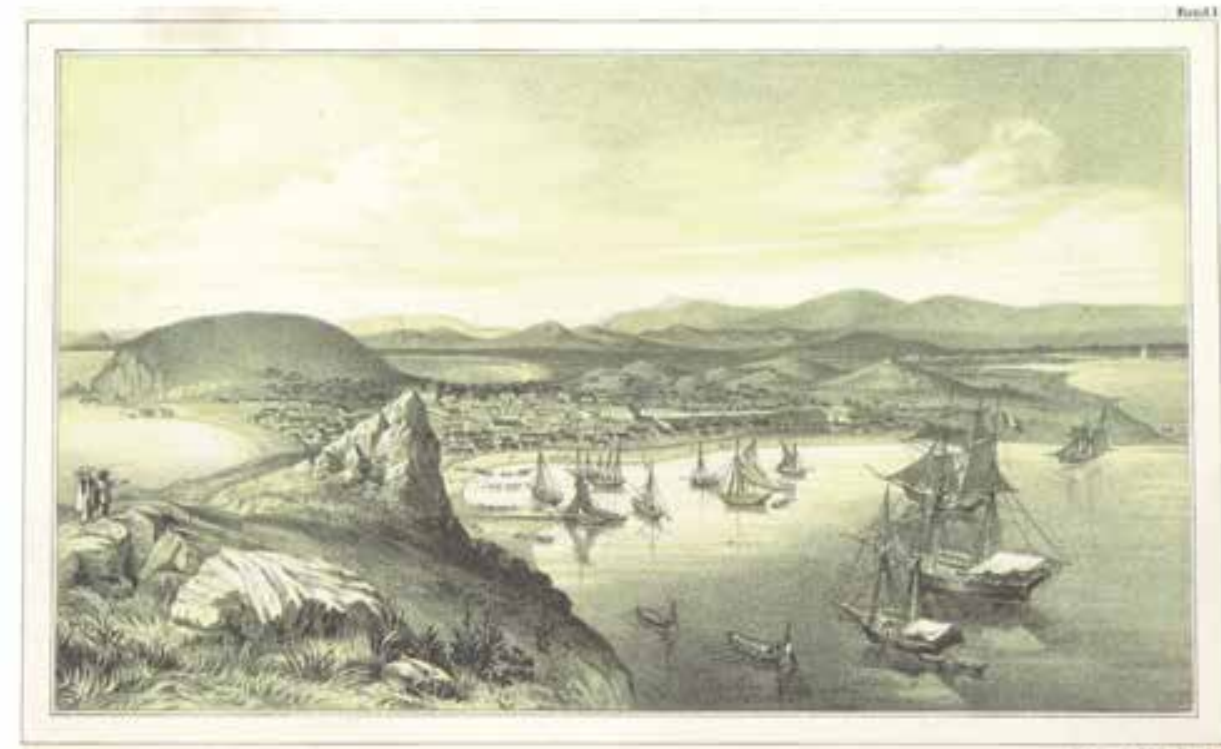

WAZAPGiAY.

Mazatlán, c. 1845. From Berthold Carl Seeman, Reise um die Welt und drei Fahrten der Königlich Britischen Fregatte Herald nach dem nördlichen Polarmeer zur Aufsuchung Sir J. Franklin's in den Jahren 1845-1851 ... (British Library)

movement to stand down and respect US control. ${ }^{24}$ The American declaration of war ended Seymour's concerns over California, but Oregon remained unresolved until word of a diplomatic settlement arrived in August. ${ }^{25}$

While the blockade in the Gulf of Mexico proceeded smoothly, the west proved more problematic. Seymour's initial orders were to respect a "legal" blockade, mirroring Austen's instructions as well as those he received from the Foreign Office. ${ }^{26}$ Commodore Robert Stockton, who replaced the ailing Sloat in mid-July, proclaimed blockade off all ports south of San Diego, some 2500 miles of coastline, that August. ${ }^{27}$ Perhaps, Stockton believed that the rapid collapse of

24 Seymour acknowledged that the US could not annex California outright, but that it was a "provisional" acquisition pending the outcome of the war. "I recommend to you the strictest Neutrality between contending Parties, and to conduct yourself with prudence and circumspection...." Seymour to Forbes, 22 July 1846, in "Documentary," California Historical Society Quarterly 3, no. 1 (April 1924): 88, https://doi.org/10.2307/25613604. American histories of events all note Seymour's visit, but after that, British involvement disappears.

25 Gough, "Royal Navy and the Oregon Crisis," 35.

26 Seymour's papers contain an 1844 Memorandum from the Foreign Office regarding blockades. Consular officials were to "abstain from any expression of opinion on blockades," but this restriction was "not wholly applicable" to naval officers. He encouraged them to be "cautious and discrete," but use their own judgement. Miscellaneous papers, Papers of Admiral George Seymour, NLA. Seymour to Dent, 2 September 1846, Special Letterbook, Papers of Admiral George Seymour, NLA.

27 Stockton to Bancroft, 28 August 1846, Pacific Squadron Letters, RG 45, M89, NARA. He enclosed a copy of his blockade proclamation, dated 19 August. Stockton reported he had "ended the 
Mexican California would allow him to shift his forces southwards, but the officer misjudged the situation. With only three ships available, he believed they could maintain an intermittent blockade while simultaneously cruising the western coast for privateers and prizes. Stockton's proclamation and assertion of US control of California triggered a series of revolts that further pinned down US forces through the end of 1846. His proclamation was the epitome of a "paper blockade." It not only violated traditional US interpretations of a blockade regulations, but his own orders. ${ }^{28}$

British reactions were swift. Diplomatically, protests went from consulates to Mexico City and to both London and Washington. The US government quickly disavowed Stockton, adding that he "did not intend ... a paper blockade" and his declaration was "liable to misconstruction." Corrective orders had been issued, inferring Stockton "did not regard" the thousands of miles of coastline covered in his proclamation. ${ }^{29}$ His mismanagement of California as well as the blockade led to his recall. In the Pacific, Seymour fired off a protest to Stockton and asked his officers to "reacquaint" US officers with blockade regulations. ${ }^{30}$ Off Mazatlán and Guaymas, Royal Navy officers visited with their US counterparts and discussed the matter, though these discussions seemed more academic than bellicose. US commanders agreed that if their ships left the area, the port was open and the blockade needed to be reestablished. ${ }^{31}$ In Callao, Seymour encountered Commodore James Biddle, the new US squadron commander, who had had just received Washington's directives. Biddle repealed Stockton's declaration and agreed it violated traditional US and international interpretations. ${ }^{32}$ Perhaps

war and restored peace and harmony" in California. His blockade proclamation was not included in Mexican War Correspondence. Seymour respected Sloat, calling him a "steady old officer," but saw Stockton as "more eager" for action. Seymour to Bankhead, 8 May 1846, Private Letterbook, Papers of Admiral George Seymour, NLA.

28 Bancroft to Sloat, 13 May 1846, 15 May 1846, "Mexican War Correspondence," House Executive Document 60, 30th Cong., 1st Sess., 233-6. In his letter cited above, he acknowledged receipt of the orders by 28 August, but took no action to rescind or modify them.

29 James Buchanan to Richard Packenham, 29 December 1846, in The Works of James Buchanan (Philadelphia: James P. Lippincott, 1907), 7:180-1; Mason to Commanding officer...Pacific, 24 December 1846, House Executive Document 8, 30th Congress, 2nd Session, 1303-4; Mason to T. A. C. Jones, 28 Oct. 1847, House Executive Document 8, 30th Congress, 2nd Session, 1304-6.

30 Seymour to Baldwin Walker, 24 December 1846, Special Orders, Papers of Admiral George Seymour, NLA.

31 Bankhead to Palmerston, 30 April 1847, FO 50/209, TNA; Baldwin Walker to Seymour, 26 March 1847, copy in FO 50/209, TNA. This note described Captain Montgomery of USS Portsmouth as having the "highest consideration for neutrals" and complemented the "considerate manner in which he has performed a disagreeable duty, [and] has won the golden opinions of all." Robert Erwin Johnson, Thence Around Cape Horn: The Story of United States Naval Forces in the Pacific Station, 1818-1923 (Annapolis: Naval Institute Press, 1963), 86.

32 Seymour to Admiralty, 9 June 1847, Special Letters, Papers of Admiral George Seymour, NLA; Biddle to Bancroft, 3 January 1847, Pacific Squadron Letters, RG 45, M89, NARA. Biddle reported the Stockton blockade was inconsistent with US blockade in the war with Tripoli as well as US treaties with Mexico. 
looking to the future, the Admiralty debated what constituted legally breaking a blockade and thus required its reinstitution. Temporary withdrawal of a blockading ship because of bad weather would not count as abandonment, but removal from the coast during the rainy "monsoon" season or keeping a more distant blockade during the summer fever season were questions for debate. ${ }^{33}$ By early 1848 , US forces maintained a "strict" blockade of the western ports not in their possession. ${ }^{34}$ The blockade had minimal impact. British warships transported specie, the single largest commodity, with several million-dollar shipments. ${ }^{35}$

One additional issue that arose was British goods captured on Mexican vessels. This was "an interesting question" as many long-term British merchants in Mexico who had become residents to avoid the Mexican duties now claimed neutral status for properties captured on Mexican ships. ${ }^{36}$ The British government and naval commanders chose not to intervene, allowing individual cases to be settled by US prize courts. Those courts existed in the southern US, and Biddle established a prize court in Monterey for western cases. ${ }^{37}$

As predicted, privateering became an issue in late June 1846, when Mexico dispensed commissions. ${ }^{38}$ Bankhead immediately protested several provisions of the Mexican law. Britain insisted that any privateer needed to be a Mexican vessel

33 Foreign Office to Bankhead, 28 February 1847, FO 50/209, TNA. Temporary relocation due to weather did not negate a blockade. If ships left to perform "other services," however, it was invalid. Biddle to William Shubrick, 17 April 1847, Pacific Squadron Letters, RG 45, M89, NARA. Biddle informed his subordinate that he could "temporarily" lift the blockade of Guaymas and Mazatlán "for bad weather," but advised him to leave the coast during the fever season, June to October. The Command situation in the Pacific was confused and complicated. Stockton had been sent assume command from Sloat in 1846, however, Biddle, who was returning from an assignment in Asia, was to be squadron commander. To confuse things more, if Biddle did not want command, it would revert to Shubrick, who had been dispatched in fall 1847 to replace Stockton, if Biddle declined or returned. Shubrick had actually assumed command when Biddle arrived and reluctantly would serve under Biddle. To bring some order to the mess, the Navy Department appointed and dispatched Captain Thomas Ap Catesby Jones to command in fall 1847. Confused? So was the Polk administration. Washington was never quite sure who was in command through 1847. Robert Erwin Johnson's history of the Pacific Squadron, Thence Around Cape Horn, entitled his Mexican American War chapter "Too Many Commodores."

34 Shubrick to Mason, 21 February 1848, House Executive Document 1, 30th Cong., 2nd sess., 1131-2.

351845 statistics are from "Commercial Tariffs and Regulations, Resources, and Trade ... Part the $16^{\text {th }}$ State of Mexico" Command Papers, House of Commons, 1846, 272-6. Courtesy of ProQuest. HMS Frolic shipped \$1.5 [million?] in February 1847. Seymour to Admiralty, 26 February 1847, Special letters, Papers of Admiral George Seymour, NLA. \$1.9 million on HMS Constance, Seymour to Admiralty, 29 August 1847, Official Letterbook, Papers of Admiral George Seymour, NLA; \$900,000 HMS Spy, Seymour to Admiralty, 29 January 1848, Official Letterbook, Papers of Admiral George Seymour, NLA.

36 Mason to Jones, 28 October 1847, House Executive Document 8, 30th Cong., 2nd Sess., 1304-5.

37 Mason to Commanding officer ... Pacific, 24 December 1846 and Mason to TAC Jones, 28 Oct. 1847, House Executive Document 8, 30th Cong., 2nd Sess., 1303-6.

38 Robert L. Scheina, "Sea Power Misused: Mexico at War, 1846-1848," The Mariner's Mirror 57 (1971): 210-1, doi:10.1080/00253359.1971.10658596. 
with a Mexican crew. When Mexico took steps to allow foreigners to become instant naturalized citizens by serving in the Mexican armed forces, it raised concerns for both the British and Americans. ${ }^{39}$ In October, when Mexico dispatched two agents of "indifferent character" to Havana with blank commissions, Bankhead spread the alarm. ${ }^{40}$ Austen feared "unprincipled Adventurers of every class, actuated by the basest motives" would use them against all shipping. He feared the Gulf would be "infested" with privateers. As a deterrent, Austen wanted to treat foreigners with Mexican commissions as pirates, subject to the death penalty, but the attorney general of Bermuda disagreed..$^{41}$ Austen publicized the order as a deterrent, but told his officers to use discretion. ${ }^{42}$ The Foreign Office echoed his concerns. ${ }^{43}$ The feared wave of privateers never emerged. The American blockade limited the ability of ships to get to sea. President Polk claimed American diplomatic pressure on Spain prevented the granting of letters of marque out of Havana, but Britain also pressured Madrid. ${ }^{44}$ While Austen was not allowed to treat privateers as pirates, the US did, implementing a piracy law in March 1847.45

Part of the American strategy was to first blockade the Mexican ports and then seize them. This complicated Anglo-American relations. In November 1846, American naval forces seized Tampico, which along with Vera Cruz, was a significant British trading center. As American naval forces closed in, British merchants feared American occupation and potential depredations by American volunteers. Captain Henry Matson of HMS Daring arrived on the eve of the American attack. The Mexican merchants sold their vessels to a British merchant and registered the sale with the British consul. Matson doubted the transaction's legality and noted he would not interfere if they were captured. ${ }^{46} \mathrm{He}$ did not. ${ }^{47}$ The city was taken without a fight, but the US refused to lift the blockade for foreign ships, insisting that neutral cargos were welcome, but only in American vessels. Matson complained to Conner about the hardship merchants faced and both Austen and Bankhead notified London that this policy caused "serious injury to our merchants." ${ }_{48}$ Matson described his exchange with Conner as "most courteous," but

39 Scheina, "Sea Power Misused," 211.

40 Bankhead to Austen, 6 October 1846, ADM 1/5560, TNA; Bankhead to Lambert, 30 October 1846, ADM 1/5560, TNA.

${ }_{41}$ Austen to Admiralty, 20 November 1846, ADM 1/5560, TNA; Vindictive Order Book, Francis Austen papers, Standing Order, AUS 11, NMM.

42 Austen to Admiralty, 19 December 1847, ADM 1/5576, TNA.

43 Palmerston to Bankhead, 20 January 1847, FO 50/208, TNA.

44 State of the Union, 8 December 1846, Senate Executive Document 1, 29th Cong., 2nd Sess., 23-

4.

45 United States Statutes at Large, 29th Cong., 2nd Sess., 175.

46 Matson to Lambert, 21 November 1846 and Enclosure in Austen to Admiralty, 19 December 1846, ADM 1/5576, TNA.

47 Austen to Admiralty, 19 December 1846 and W. D. Miller to Austen, 8 December 1846, ADM $1 / 5576$, TNA.

48 Austen to Admiralty, 19 December 1846, ADM 1/5576, TNA; Bankhead to Palmerston, 29 January 1847, FO 50/208, TNA. 
Conner would not give way, only offering to forward Matson's written grievances to Washington. ${ }^{49}$ Washington backed Conner at first, but American policy soon changed..$^{50}$ As the war dragged on, the administration sought ways to meet the steadily rising costs. By allowing neutral trade in occupied ports on the same terms as the US, it would raise revenue and eliminate neutral objections. Since the rates were lower than the Mexican duties, most merchants were pleased. ${ }^{51}$ However, some had negotiated monopolies over certain commodities, such as tobacco and silver, and implored the British government to intercede with the Americans on their behalf. ${ }^{52}$ An unsympathetic Foreign Office refused, and insisted any losses were Mexico's responsibility. ${ }^{53}$

By spring 1847, the Americans began occupying ports in Baja California and on the west coast. The general pattern was an ultimatum to Mexican officials, petitions by neutral merchants fearing destruction of their goods, and capture following a brief battle. Once under US control, American officers imposed trade regulations. ${ }^{54}$ In the case of Mazatlán, the captain of HMS Spy assisted in negotiating the port's surrender. As in the east, occupation was actually preferable to blockade. Neutral trade resumed, with lower duties. ${ }^{55}$

One by one, Mexico's eastern ports fell, leaving the largest, Vera Cruz under blockade until the long anticipated American assault materialized in March 1847. At the siege's outset, Matson sought permission from Conner to withdraw British and other foreign nationals and their property to Royal Navy vessels. When only personal baggage was allowed, Matson protested to Conner that it skirted international law, urging him to reconsider in "this more enlightened age of reason." ${ }_{56}$ Connor agreed. ${ }^{57}$ Over fifty people, mostly women and children, took refuge on HMS Hermes. As the bombardment began, the international community

49 Matson to Lambert, 21 November 1846; Matson to Conner, 17 November 1846; and Conner to Matson, 20 November 1846, ADM 1/5576, TNA.

50 Mason to Conner, 16 December 1846, House Executive Document 19, 30th Cong., 2nd Sess., 98-99.

51 Pakenham to Palmerston, 2 April 1847, FO 115/97, TNA.

52 Bankhead to Palmerston, 30 April 1847 and Tampico Consul Ewen Macintosh to Bankhead, 29 April 1847, FO/209, TNA.

53 Foreign Office to Bankhead, 30 June 1847, FO 50/207, TNA. One of the most brazen acts of transferring Mexican property to British subjects was when Mexico's government sold its two most advanced iron hulled steamships, the Guadalupe and Montezuma to a British merchant for $\$ 500,000$. Upon assurance that the two vessels were bona fide British property, the Americans allowed the two vessels to sail to Havana with a navy lieutenant on board.

54 John Lavallette to Montgomery, 21 October 1847, HED 1, 30th Cong., 1st Sess., 1082-3. See also William Shubrick to John Mason, 26 November 1847, letter plus enclosures, 30th Cong., 1st Sess., 1105-10. The Americans also allowed free importation of quicksilver and export of specie. By war's end, the US occupied Upper California, ports in Baja California (La Paz, San Jose de Cabo, San Lucas), plus Guaymas, Mazatlán, San Blas, and Acapulco.

55 Seymour to Admiralty, 29 January 1848, Official Letterbook, Papers of Admiral George Seymour, NLA.

56 Matson to Conner, 27 February 1847, ADM 1/5576, TNA.

57 Conner to Matson, 27 February 1847, 4 March 1847, ADM 1/5576, TNA. 
sought a further ceasefire to remove all non-combatants. They appealed to Matson, who contacted the new US commander, Matthew Perry, who then referred them to overall commander General Winfield Scott. Scott refused, insisting that any truce be part of surrender negotiations. When the city capitulated soon after, Scott immediately lifted the blockade, established a customs house, and allowed trade..$^{58}$ With the capture of Vera Cruz, the naval phase of the Mexican American war in the gulf largely concluded. ${ }^{59}$

Other issues would surface. The Mexican government claimed that boats from the American Squadron had entered its ports under the British flag to gain supplies. Irate Mexican officials demanded the British take action or they would fire upon any vessel under British colors. Bankhead doubted the veracity of Mexican claims, but still passed the complaint to London. An incensed Captain Pelly also doubted the story and threatened "most serious consequences" if Mexico fired on any of his ships. ${ }^{60}$ London, however, took the charges more seriously and formally protested. In meetings in May 1847 with Secretary of State James Buchanan and Secretary of the Navy John Mason, the Americans vehemently denied the accusation, but acknowledged that "in some moment of thoughtlessness" a junior officer may have participated in such a ruse, but if it did happen, it would not be repeated. ${ }^{61}$ In Acapulco, Mexican authorities briefly detained a British landing party, but Seymour blamed the mistake on Mexican authorities being unable to distinguish his men from "North Americans." 62

In August 1847, another crisis arose when a mail packet delivered former Mexican President General Mariano Paredes into Vera Cruz. Perry immediately sent a heated letter to Lambert that the landing was done with the "knowledge and connivance" of the ship's officers. ${ }^{63}$ Lambert distanced himself from the alleged plot, pointing out that the mail packets were not tied to the government, merely in contract with it. ${ }^{64}$ Buchanan formally protested, adding that allowing the continued operation of Royal Mail steamers was a "special indulgence" by the United States. ${ }^{65}$ In London, after a brief investigation, the mail packet officer was discharged from service. ${ }^{66}$

\footnotetext{
58 Austen to Admiralty, 12 April 1847; Matson to Austen, 2 April 1847; Matson to Perry, 27 March 1847; Perry to Matson, 27 March 1847, 29 March 1847, ADM 1/5576, TNA.

59 By war's end, the US also occupied, Tampico, Tabasco, and other smaller ports.

60 Lambert to Bankhead, 9 December 1845 and Lambert to J. F. Ramirez, 29 Dec 1846, ADM $1 / 55 / 76$, TNA. In addition, the Admiralty ordered Austen to work with the Mexicans to develop a set of signals to avoid any misunderstandings, Admiralty to Austen, 24 April 1847, ADM 128/2, TNA.

${ }_{61}$ Pakenham to Palmerston, 13 May 1847, enclosure in Admiralty to Austen, 15 June 1847, ADM $128 / 2$, TNA.

62 Seymour to Admiralty, 26 February 1847, Papers of Admiral George Seymour, NLA.

63 Perry to Lambert, 21 August 1847, ADM 1/5576, TNA.

64 Austen to Admiralty, 3 October 1847, ADM 1/5576, TNA.

65 John F. Crampton to Palmerston, 29 Aug 1847, FO 115/97, TNA; Buchanan to Bancroft, 14 September 1847, House Executive Document 25, 30th Cong., 1st Sess., 27-8.

${ }_{66}$ Palmerston to Bancroft, 16 November 1847, House Executive Document 25, 30th Cong., 1st Sess., 29. Similarly, in August 1846, former Spanish President Santa Anna travelled to Vera Cruz
} 
After the war's end in spring 1848, President Polk boasted "utmost care has been taken to avoid every just cause of complaint on the part of neutral nations and none has been given, liberal privileges have been granted to their commerce in the ports of the enemy under our military occupation." ${ }^{67}$ While there were minor disagreements, the continuance of British mail steamers and the export of specie removed many potential causes for complaint. The opening of captured ports to neutrals with more liberal terms than the Mexican government also helped restore trade. Both nations shared a common attitude towards privateering and the definition of a legal blockade. Aside from policy, Austen credited "the courtesy and goodwill shown by Forces of the United States during the whole" conflict. ${ }^{68}$ Royal Navy officers interacted with their Americans counterparts in the protection of national interests earning praise from both governments. Even in the Pacific, where the American blockade violated accepted norms, professionalism prevented issues from expanding. In the end, a small number of Royal Navy vessels successfully performed their mission of protecting British lives and property while observing the "strictest neutrality." While the officers played a major role, one must also remember that the policy was set not by Austen or Seymour, but by the home government. While giving both officers discretion, the overarching emphasis on neutrality came from above. The conflict and its definitions of blockades, privateering, and neutral rights foreshadowed the 1856 Declaration of Paris, where most maritime nations of the world, except the US, accepted them, but these issues would surface again in little over a decade with the American Civil War.

Dr. Stanley Adamiak is a Professor of History at University of Central Oklahoma. (Contact: sadamiak@uco.edu).

aboard the mail steamer Arabic. Although technically a violation of neutrality Austen allowed it, provided it was not on board one of his vessels. Conner claimed that that Lambert assured him the ship only carried passengers. In reality, Santa-Anna passed the blockade as part of an American plot with Santa Anna to end the war. Instead, Santa Anna seized power and intensified resistance.

67 "State of the Union," 8 December 1847, Senate Executive Document 1, 29th Cong., 2nd Sess., 23.

68 Austen to Admiralty, 12 April 1847, ADM 1/5576, TNA. 